\title{
Phase Relationships in the Zn-Rich Corner of the Zn-Fe-Zr System
}

\author{
Changjun Wu, Xinming Wang, Daniel Liu, Zhi Li, Zhongxi Zhu, Jianhua Wang, and Xuping Su
}

(Submitted November 14, 2010; in revised form March 23, 2011)

\begin{abstract}
The phase relationships in the $\mathrm{Zn}$-rich corner of the $\mathrm{Zn}-\mathrm{Fe}-\mathrm{Zr}$ system at 450,600 and $800{ }^{\circ} \mathrm{C}$ were investigated by means of $x$-ray powder diffraction (XRD) and scanning electron microscopy coupled with energy/wave dispersive spectroscopy (SEM-EDS/WDS). Two ternary compounds were found in the system. One of them was designated as $\mathrm{ZrFe}_{2} \mathrm{Zn}_{20}$ according its narrow composition range. It is a $\mathrm{CeCr}_{2} \mathrm{Al}_{20}$-type compound with lattice parameter $a=1.3941 \mathrm{~nm}$. $\mathrm{ZrFe}_{2} \mathrm{Zn}_{20}$ is stable below $878.6^{\circ} \mathrm{C}$ and can co-exist with all binary compounds in the $\mathrm{Zn}$ rich corner of the system. The other one was designated as $\mathrm{Zr}_{2} \mathrm{Fe}_{3} \mathrm{Zn} \mathbf{n}_{5}$. SEM-WDS analysis indicated that $\mathrm{Fe}$ was hardly detected in $\mathrm{ZrZn}_{22}, \mathrm{Zr}_{5} \mathbf{Z n}_{39}$ and $\mathrm{ZrZn}_{3}$. And no $\mathrm{Zr}$ was dissolved in all Fe-Zn intermetallic compounds.
\end{abstract}

Keywords intermetallic compound, phase diagram, thermodynamic equilibrium, $\mathrm{Zn}-\mathrm{Fe}-\mathrm{Zr}$

\section{Introduction}

Hot-dip galvanizing is a popular and mature process that offers steel components effective corrosion protection. However, galvanizing Si-containing steels remains a technical challenge as it produces dull and excessively thick coatings with poor adhesion. This phenomenon is referred to as the Sandlin effect or Si reactivity by the galvanizers. ${ }^{[1-3]}$ A practical solution to this problem is galvanizing the steels in alloyed baths. At present, $\mathrm{Zn}-\mathrm{Ni}$ alloys are commonly used in the galvanizing industry. ${ }^{[4]}$ However, they afford control of Si reactivity only when the $\mathrm{Si}$ content in the steel is below 0.2 wt.\%. Mackowiak and Short ${ }^{[5]}$ demonstrated that $\mathrm{Zr}$ in the $\mathrm{Zn}$ bath effectively suppressed the excessive growth of $\mathrm{Fe}-\mathrm{Zn}$ compounds by forming a ternary compound at the growth front of the $\zeta\left(\mathrm{FeZn}_{13}\right)$ layer in the coating.

The investigation of addition of $\mathrm{Zr}$ to $\mathrm{Zn}$ bath is very limited. Sebisty ${ }^{[6,7]}$ reported that additions of 0.1 and 0.3 wt. $\% \mathrm{Zr}$ decreased the coating thickness. He suggested that the limiting growth of the $\zeta$ phase is probably due to the formation of the intermetallic particles rich in $\mathrm{Fe}$ and $\mathrm{Zr}$ which involves the dissolution of the $\zeta$ phase. Zhang ${ }^{[6]}$ believed that both $\mathrm{Zr}$ and $\mathrm{Mn}$ can inhibit the layer growth of

Changjun Wu, Xinming Wang, Zhi Li, Zhongxi Zhu, and Xuping Su, Key Laboratory of Materials Design and Preparation Technology of Hunan Province, Xiangtan University, Hunan, People's Republic of China; Jianhua Wang and Xuping Su, Key Laboratory of Advanced Metal Materials of Changzhou City, Changzhou University, Changzhou, Jiangsu, People's Republic of China; Daniel Liu, Product Technology Centre, Teck Metals Ltd., Mississauga, ON L5K 1B4, Canada. Contact e-mails: wangjh@cczu.edu.cn and wuchangjun@xtu. edu.cn.

active steels with high Si content. Thus, Mn and Zr might be an alternative addition to $\mathrm{Ni}$ for controlling the excessive reaction of the active steels in general galvanizing.

When $\mathrm{Zr}$ is added to the $\mathrm{Zn}$ bath, the bath essentially becomes a $\mathrm{Zn}-\mathrm{Fe}-\mathrm{Zr}$ ternary system. Gross et al. ${ }^{[8]}$ reported a ternary compound $\mathrm{ZrFe}_{2} \mathrm{Zn}_{20}$ with the $\mathrm{CeCr}_{2} \mathrm{Al}_{20}$-type structure in the ternary system. However, no information about the phase diagram was reported. To understand the effect of $\mathrm{Zr}$ on $\mathrm{Si}$ reactivity control, determination of the phase relationship in the $\mathrm{Zn}-\mathrm{Fe}-\mathrm{Zr}$ ternary system at the galvanizing temperature is essential. In the present work, the phase equilibria in the $\mathrm{Zn}$-rich corner of the $\mathrm{Zn}-\mathrm{Fe}-\mathrm{Zr}$ system at 450 and $600{ }^{\circ} \mathrm{C}$ were determined experimentally using combined techniques of x-ray diffraction (XRD), optical microscopy and scanning electron microscopy coupled with energy/wave dispersive x-ray spectroscopy (SEM-EDS/WDS).

Due to its importance to the galvanizing industry, the $\mathrm{Fe}-\mathrm{Zn}$ binary system has been investigated repeatedly. ${ }^{[9-11]}$ The most recent thermodynamic assessment of the system was carried out by Xiong et al. ${ }^{[12]}$ There are four intermetallic compounds, the $\zeta\left(\mathrm{FeZn}_{13}\right)$, the $\delta\left(\mathrm{FeZn}_{10}\right)$, the $\Gamma_{1}\left(\mathrm{Fe}_{5} \mathrm{Zn}_{21}\right)$ and the $\Gamma\left(\mathrm{Fe}_{3} \mathrm{Zn}_{10}\right)$ phases, in the system.

The $\mathrm{Zn}-\mathrm{Zr}$ phase diagram has been thermodynamically assessed by Arroyave and $\mathrm{Liu}^{[13]}$ based on previous investigation results. ${ }^{[14,15]}$ Six stoichiometric compounds exist in the system: $\mathrm{ZrZn}_{22}, \mathrm{Zr}_{5} \mathrm{Zn}_{39}, \mathrm{ZrZn}_{3}, \mathrm{ZrZn}_{2}, \mathrm{ZrZn}$, and $\mathrm{Zr}_{2} \mathrm{Zn}$. It needs to be mentioned that the compounds of $\mathrm{Zn}_{14} \mathrm{Zr}$ and $\mathrm{Zn}_{6} \mathrm{Zr}$ reported by Chiotti and Kilp ${ }^{[16]}$ were found to be $\mathrm{Zn}_{22} \mathrm{Zr}$ and $\mathrm{Zn}_{39} \mathrm{Zr}_{5}$ instead, respectively, in a recent study. The crystal data of all the binary and ternary compounds relevant to the equilibria in the Zn-rich corner are listed in Table 1.

\section{Experimental Methods}

Series of alloys were prepared to determine the equilibrium phases in the $\mathrm{Zn}-\mathrm{Fe}-\mathrm{Zr}$ system. The purity of raw 
Table 1 Crystallographic parameters for the binary and ternary compounds in $\mathrm{Zn}$-rich corner of the Zn-Fe-Zr system

\begin{tabular}{llllll}
\hline Compound & Prototype & $\begin{array}{c}\text { Pearson } \\
\text { symbol }\end{array}$ & $\begin{array}{c}\text { Space } \\
\text { group }\end{array}$ & $\begin{array}{l}\text { Composition } \\
\text { range (at.\%) }\end{array}$ & Ref. \\
\hline $\mathrm{ZrZn}_{22}$ & $\mathrm{Mg}_{3} \mathrm{Cr}_{2} \mathrm{Al}_{18}$ & $\mathrm{cF} 184$ & $\mathrm{Fd} \overline{3} \mathrm{~m}(227)$ & $4.3 \% \mathrm{Zr}$ & {$[17,18]$} \\
$\mathrm{Zr}_{5} \mathrm{Zn}_{39}$ & $\mathrm{Ce}_{5} \mathrm{Mg}_{41}$ & $\mathrm{mS} 88$ & $\mathrm{C} 2 / \mathrm{m}(12)$ & $11.4 \% \mathrm{Zr}$ & {$[18]$} \\
$\mathrm{ZrZn}_{3}$ & $\mathrm{TiZn}_{3}$ & $\mathrm{cP} 4$ & $\mathrm{Pm} \overline{3} \mathrm{~m}(221)$ & $25 \% \mathrm{Zr}$ & {$[15]$} \\
$\zeta\left(\mathrm{FeZn}_{13}\right)$ & $\mathrm{CoZn}_{13}$ & $\mathrm{mS} 28$ & $\mathrm{C} 2 / \mathrm{m}(12)$ & $5.9-7.1 \% \mathrm{Fe}$ & {$[19,20]$} \\
$\delta\left(\mathrm{FeZn}_{10}\right)$ & $\mathrm{FeZn}_{10}$ & $\mathrm{hP555}$ & $\mathrm{P} 6_{3} \mathrm{mc}(186)$ & $8.1-13.2 \% \mathrm{Fe}$ & {$[20,21]$} \\
$\Gamma_{1}\left(\mathrm{Fe}_{5} \mathrm{Zn}_{21}\right)$ & $\mathrm{Fe}_{5} \mathrm{Zn}_{21}$ & $\mathrm{cF} 408$ & $\mathrm{~F} \overline{4} 3 \mathrm{~m}(216)$ & $18.9-24 \% \mathrm{Fe}$ & {$[20]$} \\
$\Gamma\left(\mathrm{Fe}_{3} \mathrm{Zn}_{10}\right)$ & $\mathrm{Fe}_{3} \mathrm{Zn}_{10}$ & $\mathrm{cI52}$ & $\mathrm{I} \overline{4} 3 \mathrm{~m}(217)$ & $18-31 \% \mathrm{Fe}$ & {$[20,21]$} \\
$\mathrm{ZrFe}_{2} \mathrm{Zn}_{20}$ & $\mathrm{CeCr}_{2} \mathrm{Al}_{20}$ & $\mathrm{cF} 184$ & $\mathrm{Fd} \overline{3} \mathrm{~m}(227)$ & & {$[8]$} \\
\hline
\end{tabular}

materials, i.e., $\mathrm{Fe}$ and $\mathrm{Zr}$ powders and $\mathrm{Zn}$ chips, was 99.99 wt.\%. The mixture of the raw materials, with the weight of each constituent precisely measured, was put into a tantalum inner corundum crucible, and then sealed in an evacuated quartz tube. Each sample was heated to $1100{ }^{\circ} \mathrm{C}$ and kept for $24 \mathrm{~h}$, then quenched in water. During the course of the work, in order to minimize $\mathrm{Zn}$ loss and obtain a relatively compact sample, a bottom-quenching technique $^{[22]}$ was used. The quenched samples were then resealed and annealed at 450,600 and $800{ }^{\circ} \mathrm{C}$ for 40,30 and 20 days, respectively, to ensure the establishment of an equilibrium state. The treatment was completed with rapid water quenching to preserve the equilibrium state at high temperature.

Sections of the specimens were prepared in the conventional way for metallographic examinations. A nital etching solution was used for revealing their microstructural details and a conventional optical microscope was used for the preliminary examination of all specimens. Detailed metallographic examinations and compositional analyses of various phases in the samples were performed using a JSM-6510 scanning electron microscope (SEM) equipped with an OXFORD INCA energy dispersive $\mathrm{x}$-ray spectroscope (EDS). More precise determinations of the phase composition and the solubility were conducted using the wave dispersive $\mathrm{x}$-ray spectroscopy (WDS). The compositions reported in this study were the averages of at least five measurements. In addition, some critical alloys were carefully studied by analyzing XRD patterns generated using a BEVKER-AXS/D8 advanced x-ray diffractometer with $\mathrm{Cu} \mathrm{K} \mathrm{K}_{\alpha}$-radiation and a step increase of $0.01^{\circ}$ in the $2 \theta$ angle.

To determine the transition point of the new compound, NETZSCH DSC 404 F3 high temperature calorimeter was used. In order to prevent oxidation and the evaporation of $\mathrm{Zn}$ during the heating, the specimens were sealed in evacuated quartz tubes. Vassilev ${ }^{[23]}$ used this method in study of Ni-Sn-Bi system. The DTA calibration was performed by measuring the heat of melting of pure elements $(\mathrm{Bi}, \mathrm{Zn}, \mathrm{Al}, \mathrm{Ag}$ and $\mathrm{Au})$ using the same working conditions. The base line was determined by performing measurements on two empty quartz tubes. And the temperature uncertainty was about $\pm 0.6{ }^{\circ} \mathrm{C}$. The measurement was repeated three times.
Table 2 Alloys and phase compositions at $450{ }^{\circ} \mathrm{C}$ (at.\%)

\begin{tabular}{|c|c|c|c|c|c|}
\hline Alloys & Designed composition & Phase & Zn & $\mathrm{Fe}$ & $\mathbf{Z r}$ \\
\hline \multirow[t]{3}{*}{ A1 } & $\mathrm{Zn} 93 \mathrm{Fe} 5 \mathrm{Zr} 2$ & $\mathrm{ZrFe}_{2} \mathrm{Zn}_{20}$ & 87.1 & 8.4 & 4.5 \\
\hline & & $\eta-Z n$ & 100.0 & $\ldots$ & $\ldots$ \\
\hline & & $\zeta$ & 92.7 & 7.3 & $\cdots$ \\
\hline \multirow[t]{3}{*}{ A2 } & $\mathrm{Zn} 90 \mathrm{Fe} 8 \mathrm{Zr} 2$ & $\mathrm{ZrFe}_{2} \mathrm{Zn}_{20}$ & 86.9 & 8.8 & 4.3 \\
\hline & & $\zeta$ & 92.6 & 7.4 & $\cdots$ \\
\hline & & $\delta$ & 91.1 & 8.9 & $\ldots$ \\
\hline \multirow[t]{3}{*}{ A3 } & Zn84Fe14Zr2 & $\mathrm{ZrFe}_{2} \mathrm{Zn}_{20}$ & 85.5 & 9.8 & 4.7 \\
\hline & & $\delta$ & 84.8 & 15.2 & $\ldots$ \\
\hline & & $\Gamma_{1}$ & 81.1 & 18.9 & $\ldots$ \\
\hline \multirow[t]{3}{*}{ A4 } & $\mathrm{Zn} 75 \mathrm{Fe} 24 \mathrm{Zr} 1$ & $\mathrm{ZrFe}_{2} \mathrm{Zn}_{20}$ & 85.2 & 9.9 & 4.9 \\
\hline & & $\Gamma_{1}$ & 77.5 & 22.5 & $\ldots$ \\
\hline & & $\Gamma$ & 71.2 & 28.8 & $\ldots$ \\
\hline \multirow[t]{3}{*}{ A5 } & Zn67Fe32Zr1 & $\mathrm{ZrFe}_{2} \mathrm{Zn}_{20}$ & 85.1 & 9.8 & 5.1 \\
\hline & & $\Gamma$ & 68.5 & 31.5 & $\ldots$ \\
\hline & & $\alpha-\mathrm{Fe}$ & 4.8 & 95.2 & $\ldots$ \\
\hline \multirow[t]{3}{*}{ A6 } & Zn94Fe3Zr3 & $\mathrm{ZrFe}_{2} \mathrm{Zn}_{20}$ & 87 & 8.2 & 4.8 \\
\hline & & $\eta-\mathrm{Zn}$ & 99.8 & $\cdots$ & 0.2 \\
\hline & & $\mathrm{ZrZn}_{22}$ & 95.7 & $\cdots$ & 4.3 \\
\hline \multirow[t]{3}{*}{ A7 } & Zn84Fe3Zr7 & $\mathrm{ZrFe}_{2} \mathrm{Zn}_{20}$ & 86.5 & 8.5 & 5.0 \\
\hline & & $\mathrm{ZrZn}_{22}$ & 95.7 & $\cdots$ & 4.3 \\
\hline & & $\mathrm{Zr}_{5} \mathrm{Zn}_{39}$ & 88.1 & $\ldots$ & 11.9 \\
\hline \multirow[t]{3}{*}{ A8 } & $\mathrm{Zn73Fe} 3 \mathrm{Zr} 13$ & $\mathrm{ZrFe}_{2} \mathrm{Zn}_{20}$ & 86.3 & 8.6 & 5.1 \\
\hline & & $\mathrm{Zr}_{5} \mathrm{Zn}_{39}$ & 88.3 & $\cdots$ & 11.7 \\
\hline & & $\mathrm{ZrZn}_{3}$ & 74.8 & $\ldots$ & 25.2 \\
\hline \multirow[t]{3}{*}{9} & $\mathrm{Zn} 80 \mathrm{Fe} 15 \mathrm{Zr} 10$ & $\mathrm{ZrFe}_{2} \mathrm{Zn}_{20}$ & 85.7 & 9.2 & 5.1 \\
\hline & & $\mathrm{ZrZn}_{3}$ & 74.2 & $\cdots$ & 25.8 \\
\hline & & $\mathrm{Zr}_{2} \mathrm{Fe}_{3} \mathrm{Zn}_{5}$ & 49.2 & 29.6 & 21.2 \\
\hline \multirow[t]{3}{*}{ A10 } & Zn80Fe30Zr6 & $\mathrm{ZrFe}_{2} \mathrm{Zn}_{20}$ & 85.2 & 9.8 & 5.0 \\
\hline & & $\alpha-\mathrm{Fe}$ & 95.5 & $\ldots$ & 4.5 \\
\hline & & $\mathrm{Fe}_{23} \mathrm{Zr}_{6}$ & 12.3 & 66.2 & 21.5 \\
\hline A11 & Zn87Fe9Zr5 & $\mathrm{ZrFe}_{2} \mathrm{Zn}_{20}$ & 86.3 & 9.0 & 4.7 \\
\hline
\end{tabular}

\section{Results and Discussion}

\subsection{Phase Equilibrium in Zn-Rich Corner at $450^{\circ} \mathrm{C}$}

All phases and their chemical compositions detected in the three phase regions in the $\mathrm{Zn}-\mathrm{Fe}-\mathrm{Zr}$ alloys, after being annealed at $450{ }^{\circ} \mathrm{C}$ for 40 days, are summarized in Table 2 . The ternary compound which had a narrow composition range of 4.3-5.1 at.\%Zr, 8.4-9.9 at.\%Fe and 85.187.1 at. $\% \mathrm{Zn}$ was firmly identified. It can be approximately represented by stoichiometric formula of $\mathrm{ZrFe}_{2} \mathrm{Zn}_{20}$, which is the same as that reported by Gross et al. ${ }^{[8]}$ The ternary compound is similar to those existing in the $\mathrm{Zn}-\mathrm{Fe}-\mathrm{Ti},{ }^{[24]}$ $\mathrm{Zn}-\mathrm{Fe}-\mathrm{Ni}^{[25]}$ and $\mathrm{Zn}-\mathrm{Fe}-\mathrm{Nb}^{[26]}$ systems.

As shown in Table $2, \mathrm{ZrFe}_{2} \mathrm{Zn}_{20}$ was in equilibria with all $\mathrm{Zn}$-Fe binary compounds at $450{ }^{\circ} \mathrm{C}$. Three phases were clearly distinguished in alloys $\mathrm{A} 1-\mathrm{A} 5 . \mathrm{ZrFe}_{2} \mathrm{Zn}_{20}$ was more resistant to etching by nital and can be clearly distinguished from all $\mathrm{Zn}-\mathrm{Fe}$ binary compounds. Figure 1 and 2 show the microstructures of alloys $\mathrm{A} 2$ and $\mathrm{A} 5$, which are located in the three-phase region of $\delta+\zeta+\mathrm{ZrFe}_{2} \mathrm{Zn}_{20}$ and $\alpha-\mathrm{Fe}+\Gamma+\mathrm{ZrFe}_{2} \mathrm{Zn}_{20}$, respectively. SEM-WDS analysis indicated that no $\mathrm{Zr}$ was dissolved in any of the $\mathrm{Zn}-\mathrm{Fe}$ 


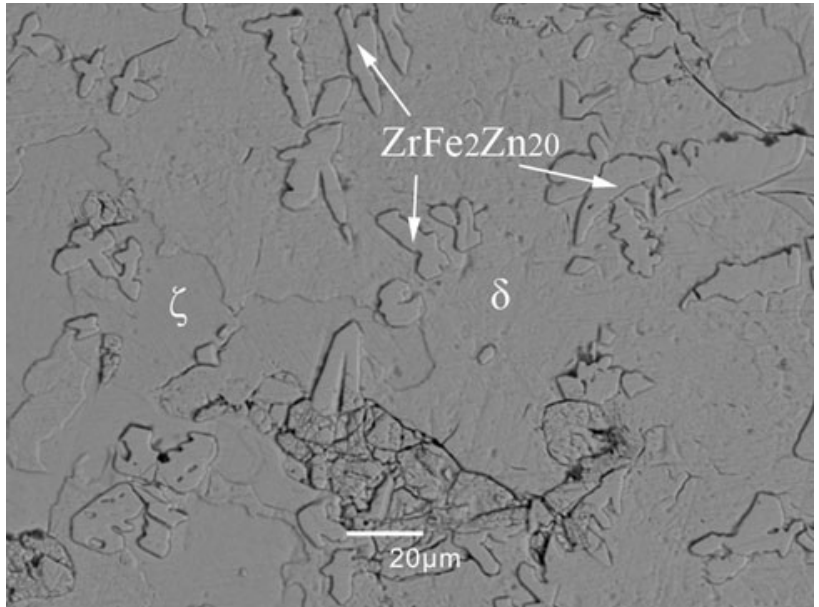

Fig. 1 BSE image of alloy A2 (Zn90Fe8Zr2). It consists of $\delta$, $\zeta$ and $\mathrm{ZrFe}_{2} \mathrm{Zn}_{20}$

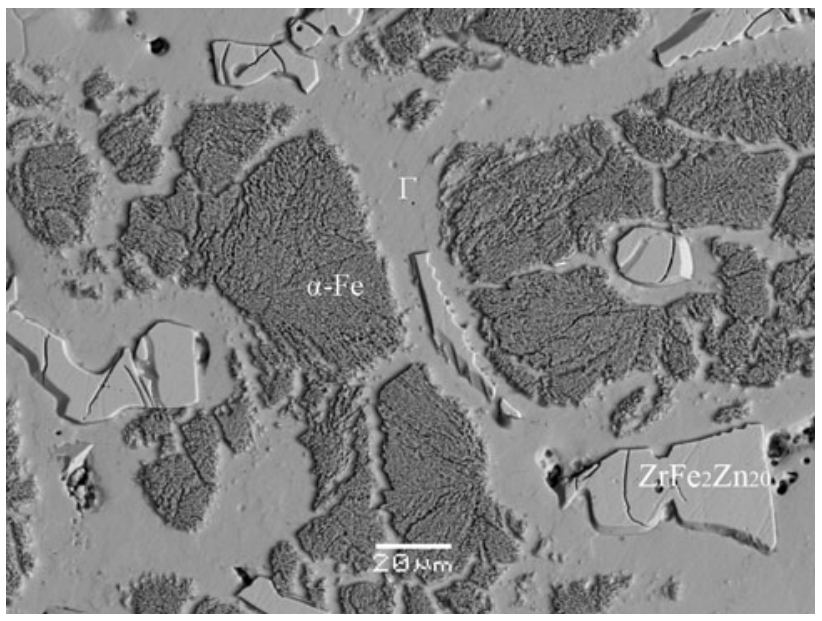

Fig. 2 BSE image of alloy A5 (Zn67Fe32Zr1). $\alpha-\mathrm{Fe}, \Gamma$ and $\mathrm{ZrFe}_{2} \mathrm{Zn}_{20}$ coexist

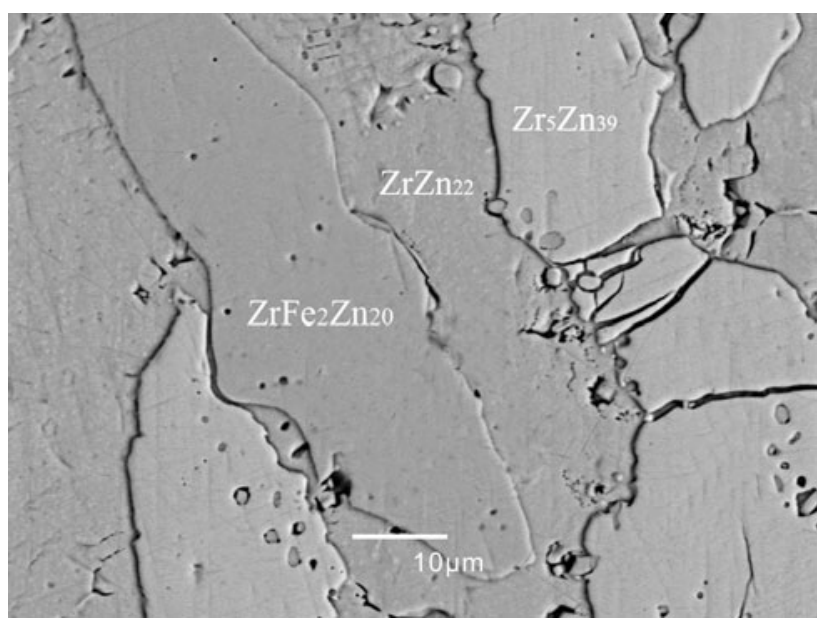

Fig. 3 BSE image of alloy A7 (Zn84Fe3Zr7) consists of $\mathrm{ZrFe}_{2} \mathrm{Zn}_{20}, \mathrm{ZrZn}_{22}$, and $\mathrm{Zr}_{5} \mathrm{Zn}_{39}$

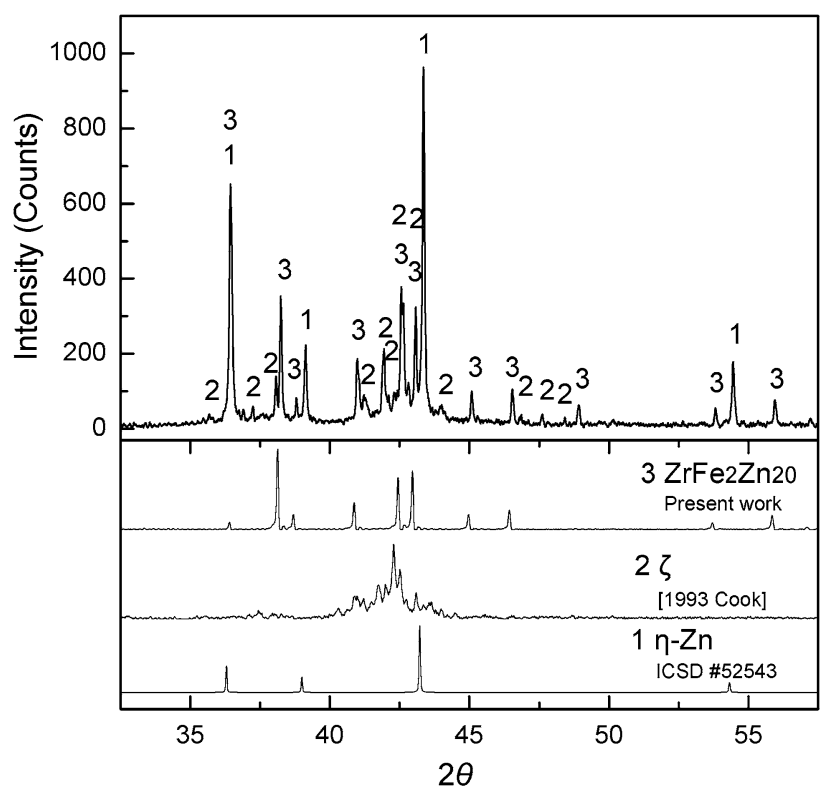

Fig. 4 X-ray pattern of alloy A1 (Zn93Fe5Zr2)

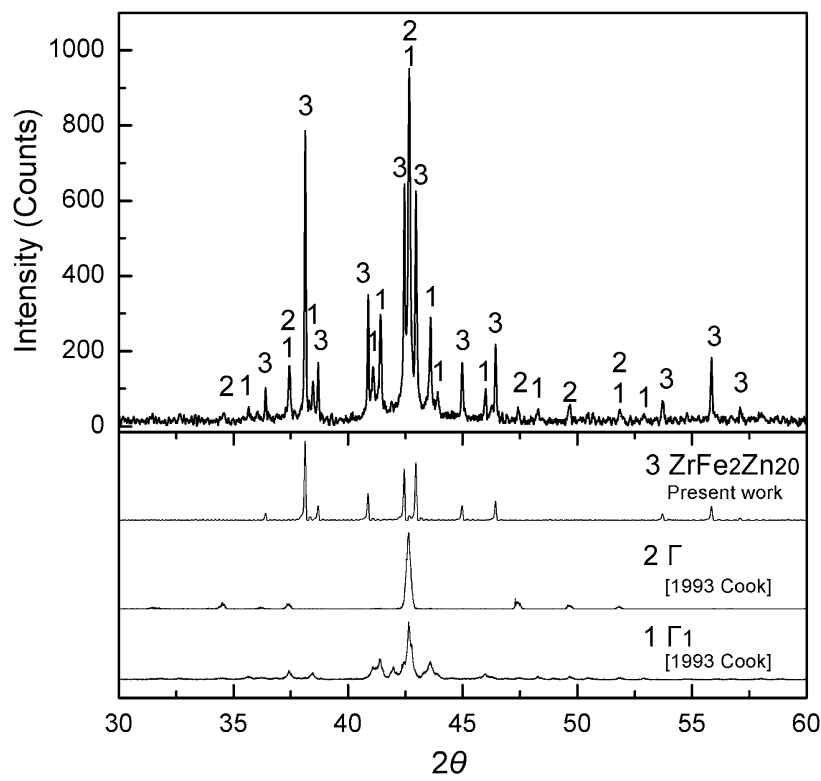

Fig. 5 X-ray pattern of alloy A4 (Zn75Fe24Zr1)

binary compounds. As can be seen from the microstructure of alloy $\mathrm{A} 7$ in Fig. $3, \mathrm{ZrFe}_{2} \mathrm{Zn}_{20}$ coexists with $\mathrm{ZrZn}_{22}$ and $\mathrm{Zr}_{5} \mathrm{Zn}_{39} . \mathrm{ZrFe}_{2} \mathrm{Zn}_{20}$ was more difficult to be etched than $\mathrm{ZrZn}_{22}$, but less than $\mathrm{Zr}_{5} \mathrm{Zn}_{39}$ and $\mathrm{ZrZn}_{3}$. Fe was hardly detected in $\mathrm{ZrZn}_{22}, \mathrm{Zr}_{5} \mathrm{Zn}_{39}$ and $\mathrm{ZrZn}_{3}$ by SEM-WDS analysis.

To further identify the $\mathrm{ZrFe}_{2} \mathrm{Zn}_{20}$ phase and confirm the relative phase equilibrium states determined by SEM-WDS, the XRD patterns of some selective alloys were generated, as shown in Fig. 4-9. It needs to be noted that the patterns of single $\zeta, \delta, \Gamma_{1}$ and $\Gamma$ were gathered from Cook and Grant ${ }^{[20]}$ and that of $\alpha$-Fe, $\eta-Z n, Z_{2} n_{22}$ and $Z_{5} Z_{3} n_{39}$ were calculated from available crystal structure data from Samson ${ }^{[17]}$ and 


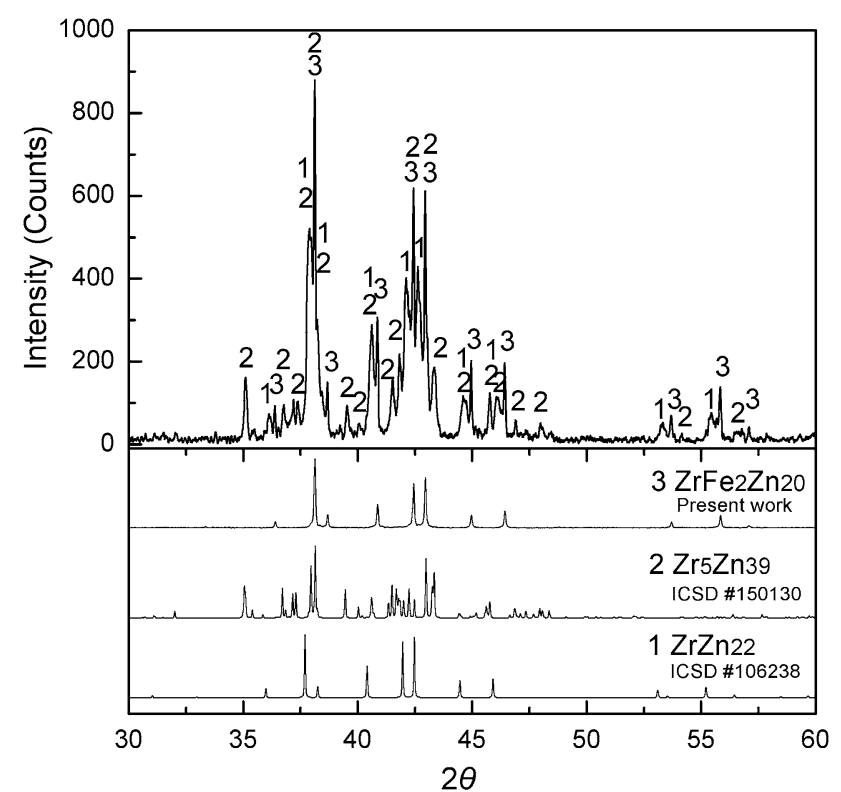

Fig. 6 X-ray pattern of alloy A7 (Zn84Fe3Zr7)

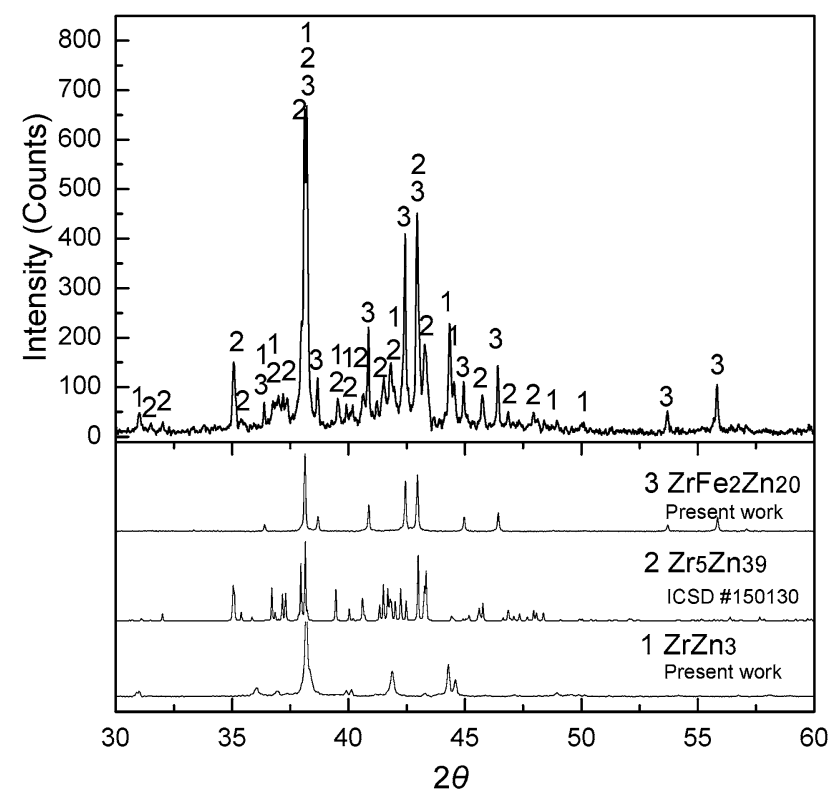

Fig. 7 X-ray pattern of alloy A8 (Zn73Fe3Zr13)

from Chen and Jeitsehko ${ }^{[18]}$. However, the XRD pattern of $\mathrm{ZrZn}_{3}$ in Fig. 7 and $8(\mathrm{~b})$ was generated from the $\mathrm{Zn}-25$ at.\%Zr alloy which was prepared by annealing the cold-pressed mixture of the $\mathrm{Zn}$ and $\mathrm{Zr}$ powders in evacuated tube at $700{ }^{\circ} \mathrm{C}$ for 30 days. Arroyave et al. ${ }^{[15]}$ first-principle calculated the enthalpies of formation for $\mathrm{ZrZn}_{3}$ with the $\mathrm{AB}_{3}$-type structures. They believed that the cubic $\mathrm{L}_{2}$ structure is likely to be the ground state for the $\mathrm{ZrZn}_{3}$ composition. However, it had no experiment supporting.
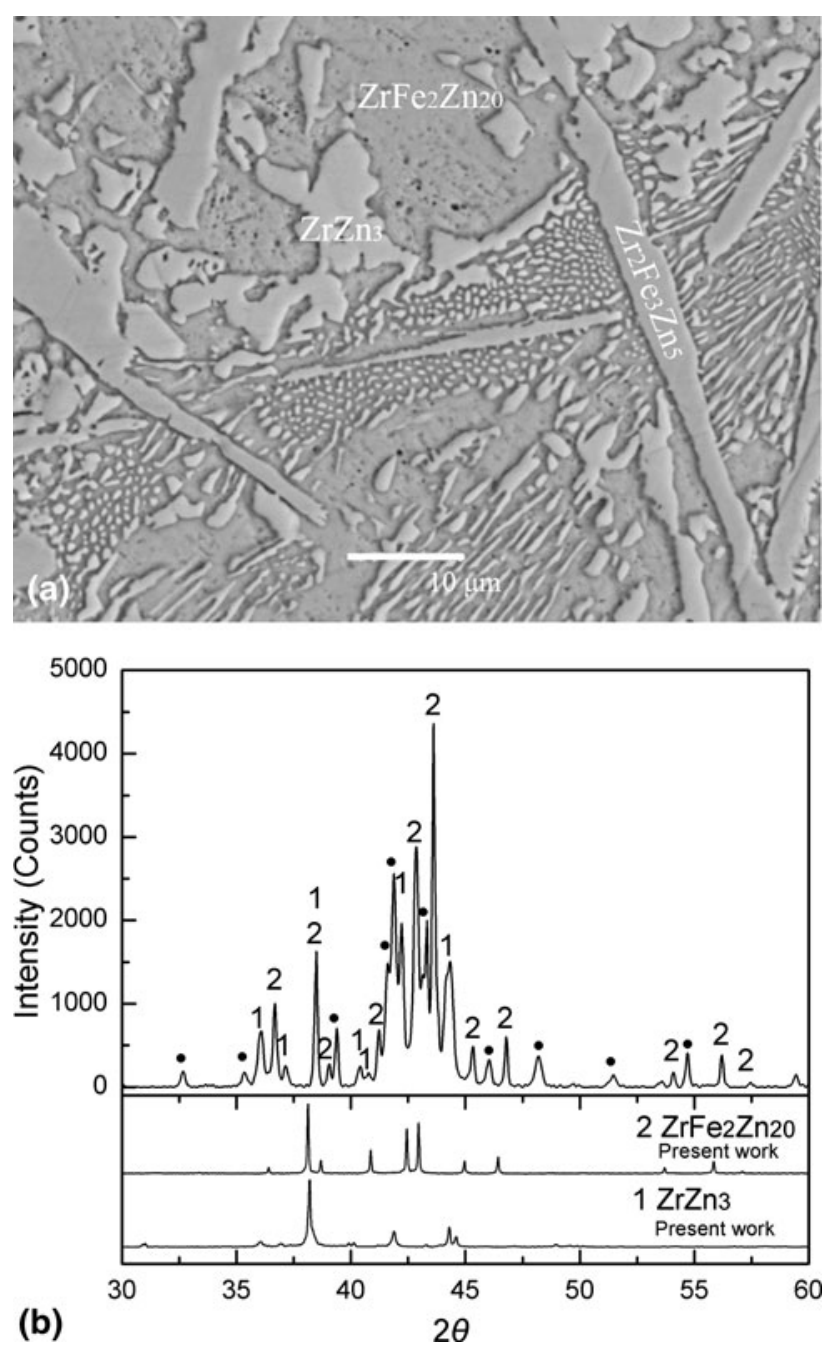

Fig. 8 (a) BSE image and (b) XRD pattern of alloy A9. It consists of three phases: $\mathrm{ZrZn}_{3}, \mathrm{ZrFe}_{2} \mathrm{Zn}_{20}$ and $\mathrm{Zr}_{2} \mathrm{Fe}_{3} \mathrm{Zn}_{5}$. The peaks, denoted by dots, may belong to the $\mathrm{Zr}_{2} \mathrm{Fe}_{3} \mathrm{Zn}_{5}$

The XRD pattern of $\mathrm{ZrFe}_{2} \mathrm{Zn}_{20}$ contained in all figures was generated from alloy A11. The alloy was prepared by the way described in Section 2 and was confirmed to be a single phase by SEM-EDS. As can be seen from Fig. 4-9, the characteristic peaks of $\mathrm{ZrFe}_{2} \mathrm{Zn}_{20}$ are clearly distinguished from all binary compounds in all alloys.

The TREOR program ${ }^{[27]}$ was used to index and calculate the pattern automatically and finally all peaks were indexed in the cubic system, resulting in the figure of merit, $\mathrm{M}(40)=26, \mathrm{~F}(40)=30$. The lattice parameter of the crystal was $1.3941 \mathrm{~nm}$, which agreed well with that reported by Gross et al. ${ }^{[8]}$ As discussed by Gross et al., both the $\mathrm{ZrFe}_{2} \mathrm{Zn}_{20}$ and $\mathrm{ZrZn}_{22}$ had the $\mathrm{CeCr}_{2} \mathrm{Al}_{20}$-type structure. Therefore, the profiles of the XRD patterns of them were similar, as shown in Fig. 6. They had a difference of $0.45^{\circ}$ $(2 \theta)$ in all peaks with $\mathrm{ZrZn}_{22}$ having the larger lattice parameter of $1.4101 \mathrm{~nm} .{ }^{[17]}$ The BSE image and XRD pattern of the alloys A7, shown in Fig. 3 and 6, respectively, indicated that $\mathrm{ZrFe}_{2} \mathrm{Zn}_{20}$ containing 9 at.\% of $\mathrm{Fe}$ is a different phase from $\mathrm{ZrZn}_{22}$. 

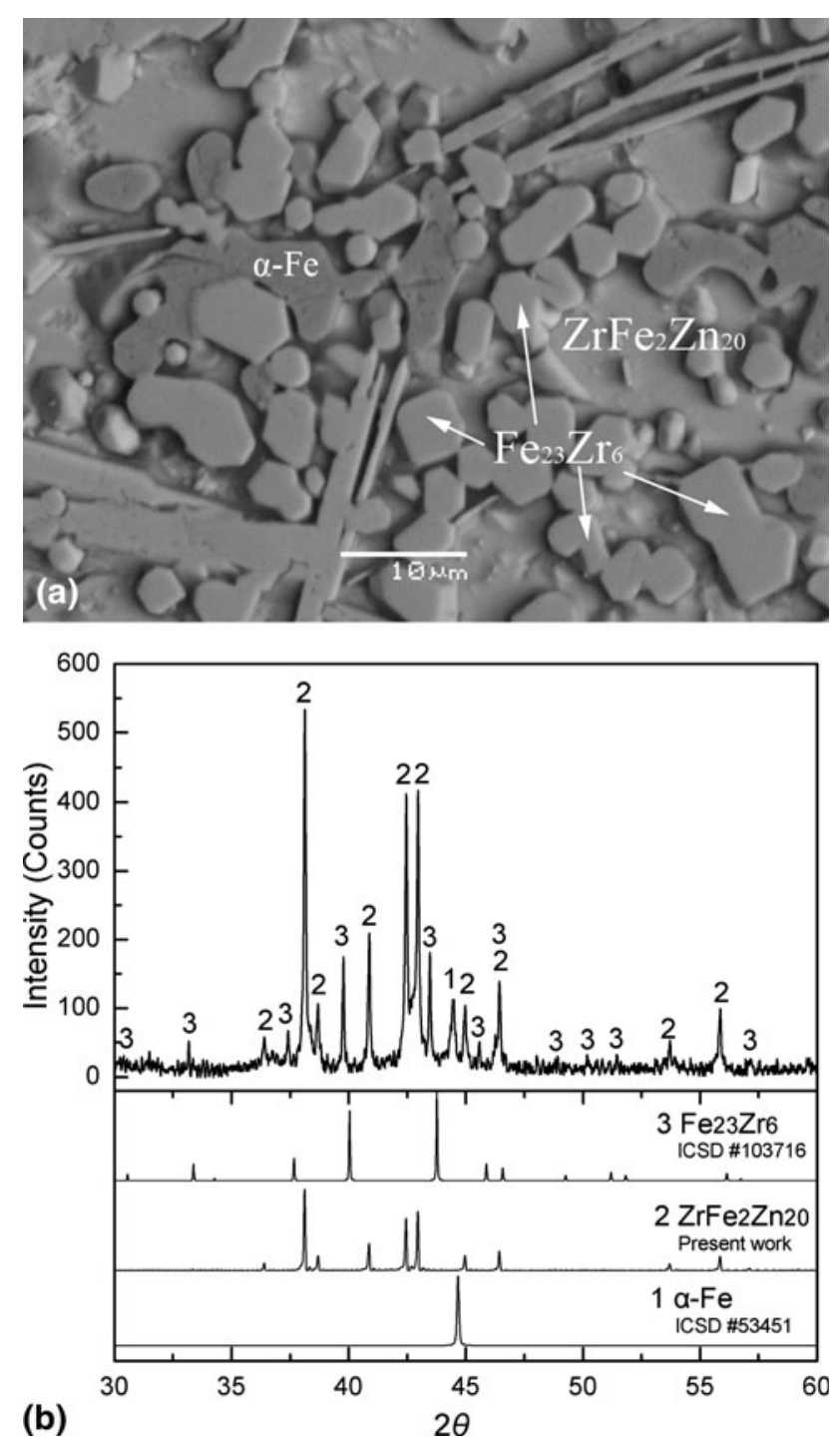

Fig. 9 (a) BSE image and (b) XRD pattern of alloy A10. $\mathrm{Fe}_{23} \mathrm{Zr}_{6}, \mathrm{ZrFe}_{2} \mathrm{Zn}_{20}$ and $\alpha$-Fe co-exist

Another ternary compound was found in alloy A9, as shown in Fig. 8(a). It coexisted with $\mathrm{ZrZn}_{3}$ and $\mathrm{ZrFe}_{2} \mathrm{Zn}_{20}$ with a little color difference from $Z Z_{3} n_{3}$. SEM-WDS analysis indicated that it contained 20 at. $\% \mathrm{Zr}, 30$ at. $\% \mathrm{Fe}$ and 50 at.\%Zn. Therefore, it was designated as $\mathrm{Zr}_{2} \mathrm{Fe}_{3} \mathrm{Zn}_{5}$. An XRD pattern of alloy A9 in Fig. 8(b) clearly shows that there are some peaks, denoted by dots, not belong to the patterns of $\mathrm{ZrFe}_{2} \mathrm{Zn}_{20}$ or $\mathrm{ZrZn}_{3}$. They can not be indexed as attributable to any of binary compound in the system.

It is important to note that 12.3 at.\% $\mathrm{Zn}$ was detected in the $\mathrm{Fe}_{23} \mathrm{Zr}_{6}$ phase in alloy A10. Three phases were clearly distinguished in the BSE image of alloy A10 in Fig. 9(a). And $\mathrm{Fe}_{23} \mathrm{Zr}_{6}$ was successfully index in the XRD pattern (Fig. $9 b$ ) but with $2 \theta$ difference of about $0.244^{\circ}$. It may be a ternary compound which has a crystal structure similar to $\mathrm{Fe}_{23} \mathrm{Zr}_{6}$ and needs further examination. At present, it was considered as $\mathrm{Fe}_{23} \mathrm{Zr}_{6}$.

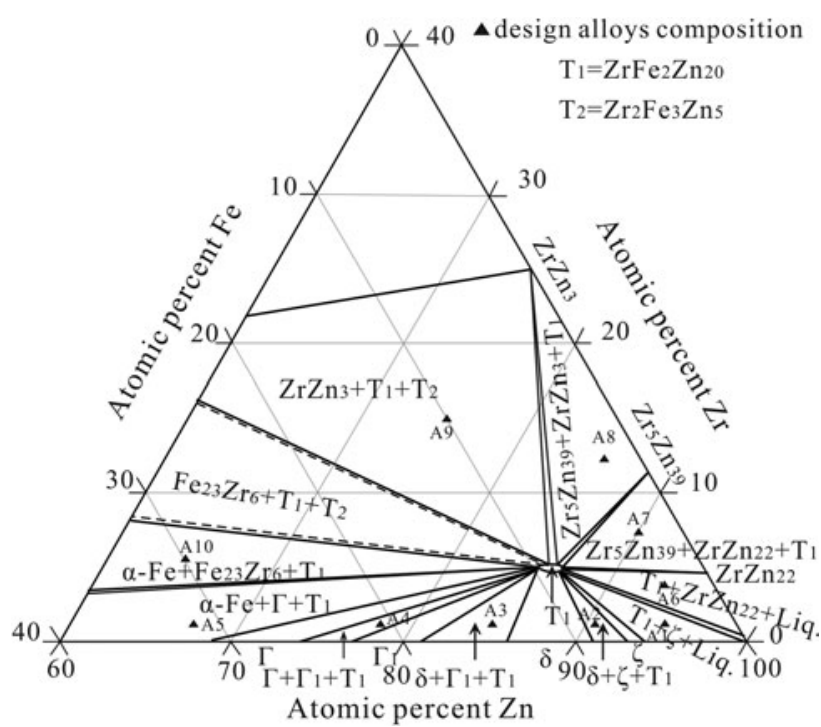

Fig. 10 The Zn-rich corner of the $\mathrm{Zn}-\mathrm{Fe}-\mathrm{Zr}$ phase diagram at $450{ }^{\circ} \mathrm{C}$

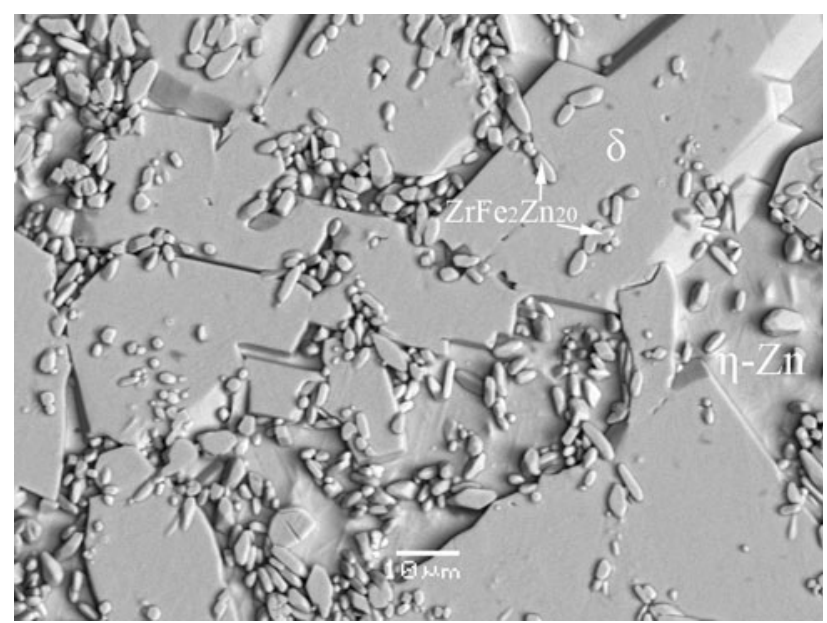

Fig. 11 SEM image of alloy B1 (Zn91Fe7Zr2)

Based on the experimental results obtained in this study and the information of relevant binary systems in the literatures, the $450{ }^{\circ} \mathrm{C}$ isothermal section of the $\mathrm{Zn}$-rich corner of the $\mathrm{Zn}-\mathrm{Fe}-\mathrm{Zr}$ system was constructed, as shown in Fig. 10. The ternary compound $\mathrm{ZrFe}_{2} \mathrm{Zn}_{20}$, which has a narrow composition range, is in equilibrium with all phases in the $\mathrm{Zn}$-rich corner and is designated as $\mathrm{T}_{1}$.

\subsection{Phase Equilibrium in Zn-Rich Corner at 600 and $800^{\circ} \mathrm{C}$}

In the present work, phase equilibrium in the $\mathrm{Zn}$-rich corner of the $\mathrm{Zn}-\mathrm{Fe}-\mathrm{Zr}$ system at $600{ }^{\circ} \mathrm{C}$ was also investigated. Some typical SEM images and XRD patterns are clearly shown in Fig. 11-13. For concise, the BSE images and XRD patterns of the alloys which lie in the same ternary phase field with that at $450{ }^{\circ} \mathrm{C}$, i.e., 

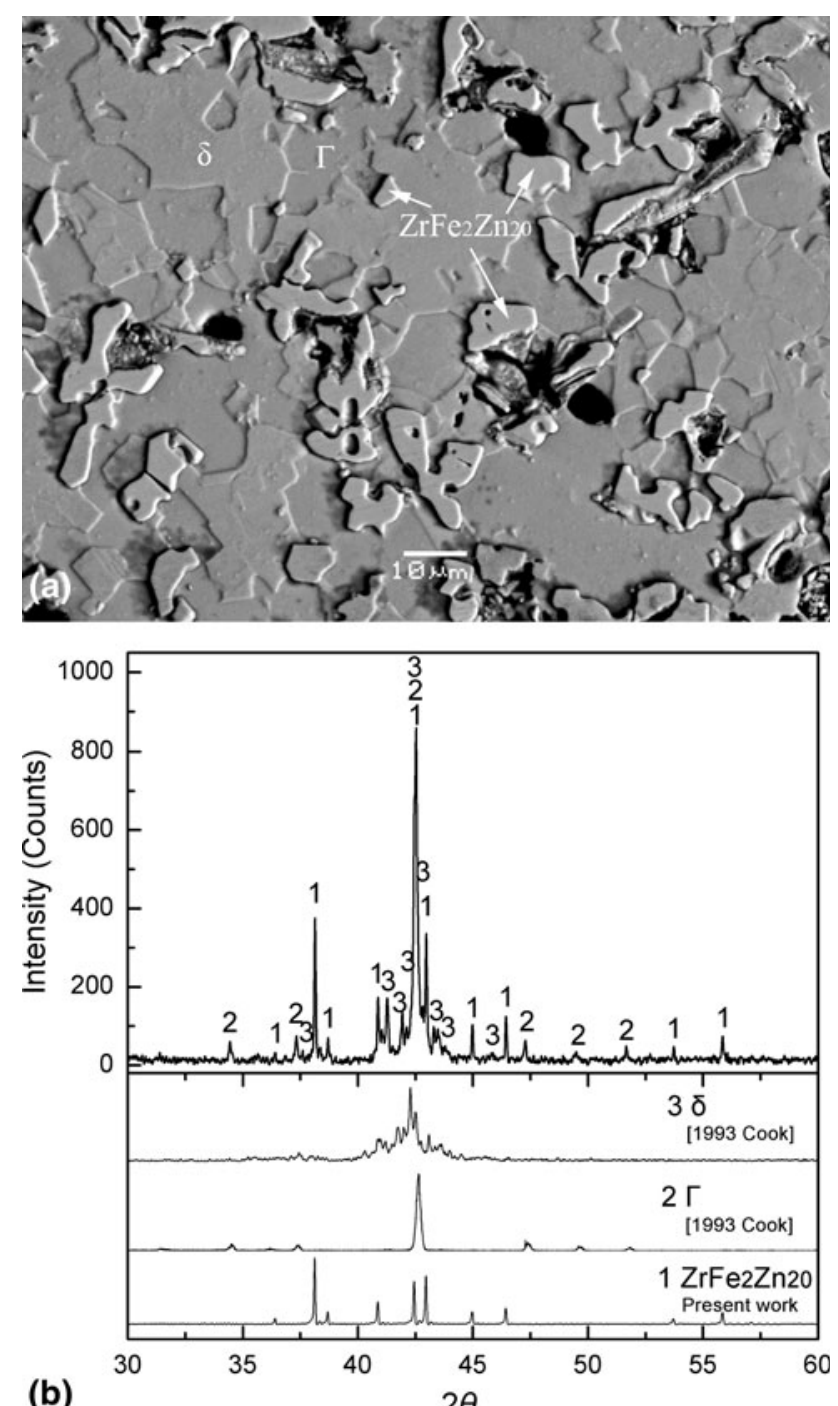

Fig. 12 (a) BSE image and (b) XRD pattern of alloy B2 $(\mathrm{Zn} 83 \mathrm{Fe} 15 \mathrm{Zr} 2) . \delta, \Gamma$ and $\mathrm{ZrFe}_{2} \mathrm{Zn}_{20}$ were equilibrated in the alloy

$\mathrm{ZrFe}_{2} \mathrm{Zn}_{20}+\mathrm{Zr}_{5} \mathrm{Zn}_{39}+\mathrm{ZrZn}_{3}$ and $\alpha-\mathrm{Fe}+\mathrm{ZrFe}_{2} \mathrm{Zn}_{20}+\Gamma$, were not shown again.

The $\mathrm{ZrFe}_{2} \mathrm{Zn}_{20}$ phase stably existed at $600{ }^{\circ} \mathrm{C}$ and coexisted with all the compounds in the Zn-rich corner. $\mathrm{ZrZn}_{22}, \zeta$ and $\Gamma_{1}$ were not found at this temperature which agrees well with the binary boundaries. The equilibria of $\delta+$ Liq. $+\mathrm{ZrFe}_{2} \mathrm{Zn}_{20}$ in alloy $\mathrm{B} 1$ is shown in Fig. 11. It should be pointed out that the $\eta-Z n$ marked in the figure was the liquid phase at the annealing temperature. The BSE image and XRD pattern of alloy B2, which show the coexistence of $\delta+\Gamma+\mathrm{ZrFe}_{2} \mathrm{Zn}_{20}$, was shown in Fig. 12(a) and (b), respectively. The pattern of alloy A11 was used to index the $\mathrm{ZrFe}_{2} \mathrm{Zn}_{20}$ phase at $600{ }^{\circ} \mathrm{C}$. SEM-WDS results in Table 3 suggested that $\mathrm{Zr}$ can not dissolve in $\delta$ and $\Gamma$ at $600{ }^{\circ} \mathrm{C}$. Besides, the XRD pattern of alloy B4 is shown in Fig. 13. Liquid, $\mathrm{Zr}_{5} \mathrm{Zn}_{39}$ and $\mathrm{ZrFe}_{2} \mathrm{Zn}_{20}$ were coexisting in the alloy. No Fe was detected in $\mathrm{Zr}_{5} \mathrm{Zn}_{39}$ and $\mathrm{ZrZn}_{3}$ by

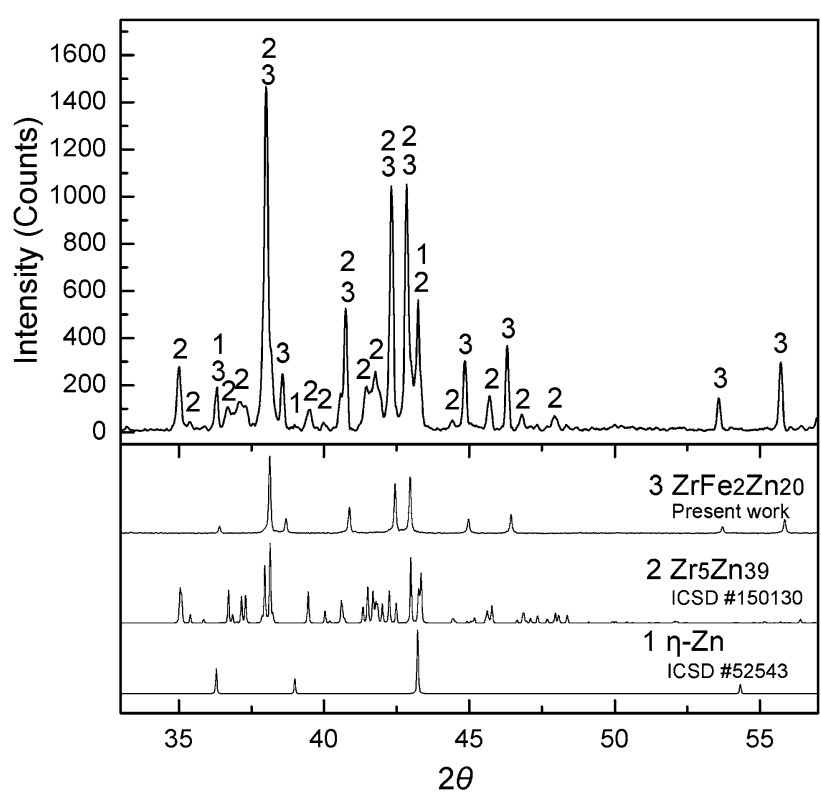

Fig. 13 XRD pattern of alloy B4 (Zn92Fe3Zr5)

Table 3 Alloys and phase compositions at $600{ }^{\circ} \mathrm{C}$ (at.\%)

\begin{tabular}{|c|c|c|c|c|c|}
\hline Alloys & Designed composition & Phase & Zn & $\mathbf{F e}$ & $\mathbf{Z r}$ \\
\hline \multirow[t]{3}{*}{ B1 } & Zn91Fe7Zr2 & $\mathrm{ZrFe}_{2} \mathrm{Zn}_{20}$ & 86.9 & 8.5 & 4.6 \\
\hline & & $\delta$ & 89.9 & 10.1 & $\ldots$ \\
\hline & & $\eta-Z n$ & 97.9 & 2.1 & $\ldots$ \\
\hline \multirow[t]{3}{*}{ B2 } & $\mathrm{Zn} 83 \mathrm{Fe} 15 \mathrm{Zr} 2$ & $\mathrm{ZrFe}_{2} \mathrm{Zn}_{20}$ & 85.4 & 9.6 & 5 \\
\hline & & $\delta$ & 85.3 & 14.7 & $\ldots$ \\
\hline & & $\Gamma$ & 78.5 & 21.5 & $\ldots$ \\
\hline \multirow[t]{3}{*}{ B3 } & Zn67Fe32Zr1 & $\mathrm{ZrFe}_{2} \mathrm{Zn}_{20}$ & 85 & 10.1 & 4.9 \\
\hline & & $\Gamma$ & 67.8 & 32.2 & $\ldots$ \\
\hline & & $\alpha-\mathrm{Fe}$ & 17.4 & 82.3 & 0.3 \\
\hline \multirow[t]{3}{*}{ B4 } & $\mathrm{Zn} 92 \mathrm{Fe} 3 \mathrm{Zr} 5$ & $\mathrm{ZrFe}_{2} \mathrm{Zn}_{20}$ & 87.2 & 8.3 & 4.5 \\
\hline & & Liq. & 97.8 & $\ldots$ & 2.2 \\
\hline & & $\mathrm{Zr}_{5} \mathrm{Zn}_{39}$ & 87.7 & $\ldots$ & 12.3 \\
\hline \multirow[t]{3}{*}{ B5 } & Zn84Fe3Zr13 & $\mathrm{ZrFe}_{2} \mathrm{Zn}_{20}$ & 86.1 & 8.7 & 5.2 \\
\hline & & $\mathrm{Zr}_{5} \mathrm{Zn}_{39}$ & 87.4 & $\ldots$ & 12.6 \\
\hline & & $\mathrm{ZrZn}_{3}$ & 74.4 & $\ldots$ & 25.6 \\
\hline \multirow[t]{3}{*}{ B6 } & $\mathrm{Zn75Fe10Zr15}$ & $\mathrm{ZrFe}_{2} \mathrm{Zn}_{20}$ & 84.49 & 9.41 & 6.1 \\
\hline & & $\mathrm{ZrZn}_{3}$ & 69.95 & 28.45 & 1.6 \\
\hline & & $\mathrm{Zr}_{2} \mathrm{Fe}_{3} \mathrm{Zn}_{5}$ & 18.31 & 51.69 & 30.0 \\
\hline
\end{tabular}

SEM-WDS analysis. The Zn-rich corner of the $\mathrm{Zn}-\mathrm{Fe}-\mathrm{Zr}$ system at $600{ }^{\circ} \mathrm{C}$ was outlined in Fig. 14.

As shown above, the $\mathrm{ZrFe}_{2} \mathrm{Zn}_{20}$ phase stably exists at $600{ }^{\circ} \mathrm{C}$. The alloy A11, which was annealed at $450{ }^{\circ} \mathrm{C}$ for 40 days and confirmed to be a single phase, was used to determine the transition point of the $\mathrm{ZrFe}_{2} \mathrm{Zn}_{20}$ phase. The alloy was enclosed in an evacuated quartz tube in DTA examination to prevent oxidation and the evaporation of $\mathrm{Zn}$. The DTA curve in Fig. 15 indicates that the transformation point of the $\mathrm{ZrFe}_{2} \mathrm{Zn}_{20}$ phase is $878.6{ }^{\circ} \mathrm{C}$. At the same time, 


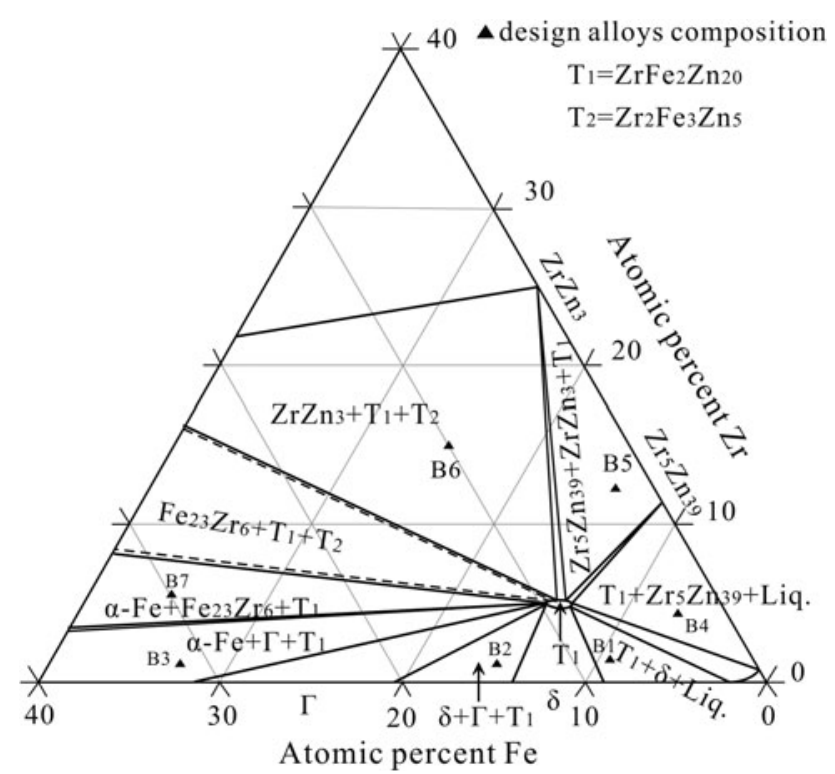

Fig. 14 The $\mathrm{Zn}$-rich corner of the $\mathrm{Zn}-\mathrm{Fe}-\mathrm{Zr}$ phase diagram at $600{ }^{\circ} \mathrm{C}$

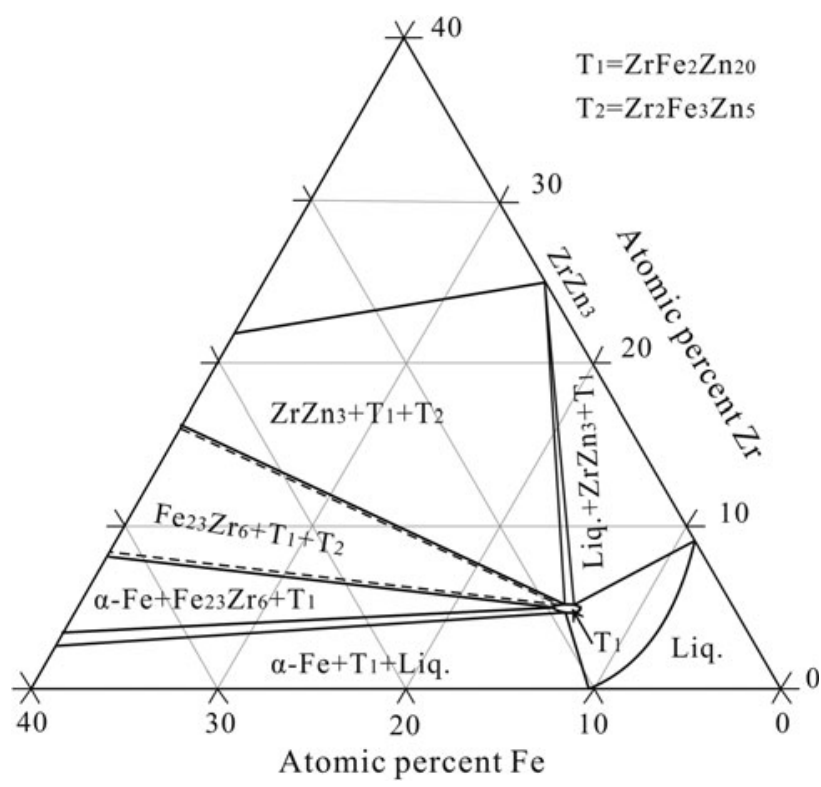

Fig. 16 The $\mathrm{Zn}$-rich corner of the $\mathrm{Zn}-\mathrm{Fe}-\mathrm{Zr}$ phase diagram at $800{ }^{\circ} \mathrm{C}$

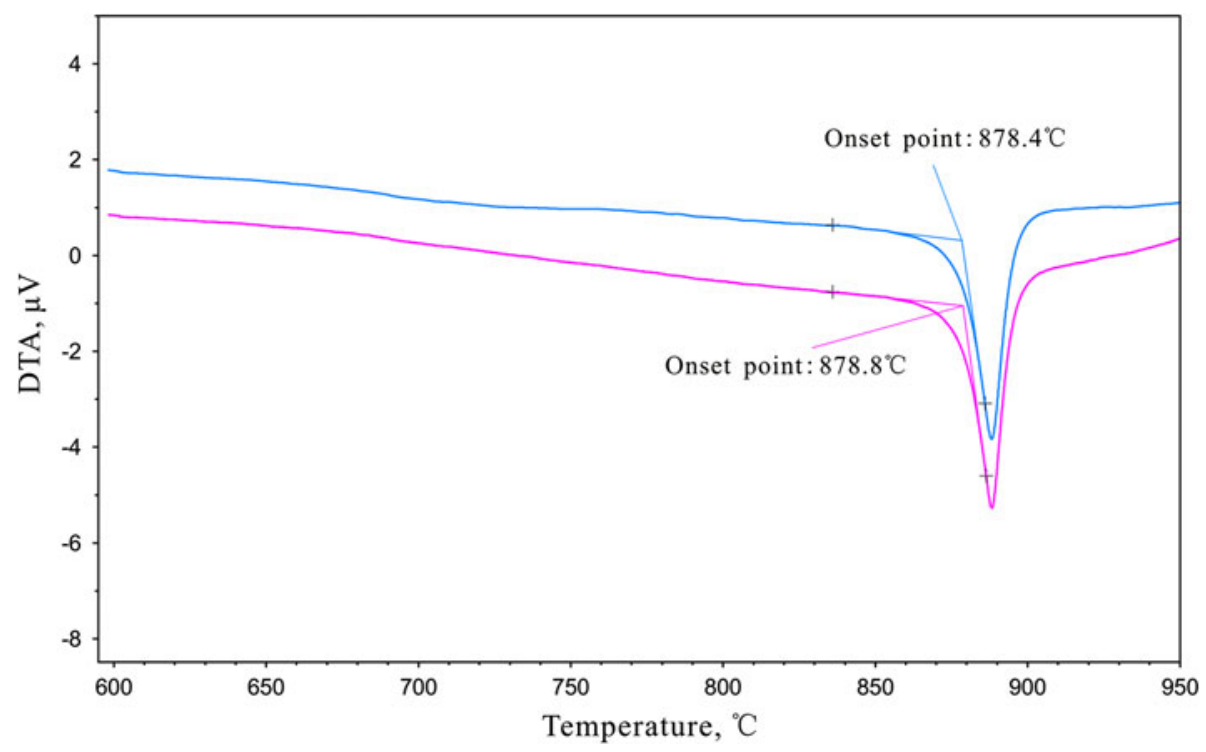

Fig. 15 DTA curve of alloy A11, the single $\mathrm{ZrFe}_{2} \mathrm{Zn}_{20}$ phase, with heating rate of $5{ }^{\circ} \mathrm{C} / \mathrm{min}$

the equilibria of Liq. $+\alpha-\mathrm{Fe}+\mathrm{ZrFe}_{2} \mathrm{Zn}_{20}$ and Liq. $+\mathrm{Zr}-$ $\mathrm{Fe}_{2} \mathrm{Zn}_{20}+\mathrm{ZrZn}_{3}$ at $800{ }^{\circ} \mathrm{C}$ were observed in the present work. The Zn-rich corner of the $\mathrm{Zn}-\mathrm{Fe}-\mathrm{Zr}$ system at $800{ }^{\circ} \mathrm{C}$ was outlined in Fig. 16.

\section{Conclusions}

Based on SEM-EDS and WDS analyses and x-ray diffraction studies, the phase relationship in the $\mathrm{Zn}$-rich corner of $\mathrm{Zn}-\mathrm{Fe}-\mathrm{Zr}$ ternary system at 450,600 and $800{ }^{\circ} \mathrm{C}$ was outlined in the present work. The solubility of $\mathrm{Zr}$ in four $\mathrm{Fe}-\mathrm{Zn}$ compounds is too limited to be detected. And Fe can not be dissolved into the $\mathrm{ZrZn}_{22}, \mathrm{Zr}_{5} \mathrm{Zn}_{39}$ and $\mathrm{ZrZn}_{3}$.

Two ternary compounds, designated as $\mathrm{ZrFe}_{2} \mathrm{Zn}_{20}$ and $\mathrm{Zr}_{2} \mathrm{Fe}_{3} \mathrm{Zn}_{5}$ according their narrow chemical composition, were found in the system. DTA test indicated that $\mathrm{ZrFe}_{2} \mathrm{Zn}_{20}$ can stably exist below $878.6^{\circ} \mathrm{C}$. The XRD pattern of the single $\mathrm{ZrFe}_{2} \mathrm{Zn}_{20}$ phase was successfully indexed. It is a $\mathrm{CeCr}_{2} \mathrm{Al}_{20}$-type compound with lattice parameter $a=1.3941 \mathrm{~nm}$. $\mathrm{ZrFe}_{2} \mathrm{Zn}_{20}$ can be in equilibrium with all phases in the $\mathrm{Zn}$-rich corner of the system. Moreover, $\mathrm{Zr}_{2} \mathrm{Fe}_{3} \mathrm{Zn}_{5}$ was found coexisting with $\mathrm{ZrFe}_{2} \mathrm{Zn}_{20}$ and $\mathrm{ZrZn}_{3}$. 


\section{Acknowledgments}

The authors gratefully acknowledge the financial support from Qinlan project, and National Natural Science Foundation of China (Nos. 50971110 and 50971111). Discussions with Dr. Nai-Yong Tang at Teck Metals are much appreciated.

\section{References}

1. R.W. Sandelin, Galvanizing Characteristics of Different Types of Steel, Wire Wire Prod., 1940, 15(11-12), p 655-676

2. J. Foct, P. Perrot, and G. Reumont, Interpretation of the Role of Silicon on the Galvanizing Reaction Based on Kinetics, Morphology and Thermodynamics, Scr. Metall., 1993, 28(10), p $1195-1200$

3. H. Guttman and P. Niessen, Reactivity of Silicon Steels in HotDip Galvanizing, Can. Metall. Q., 1972, 11(4), p 609-615

4. J. Zervoudis, G.R. Adams, V.M. Duarte, M. Gilles, and R. Sokolowski, Galvanizing of Reactive Steels (Vancouver, CA), Cominco, Ltd., United States patent 6280795, 2001 p 1-11

5. J. Mackowiak and N.R. Short, Metallurgy of Galvanizing Coatings, Int. Met. Rev., 1979, 24(1), p 1-19

6. B. Zhang, Development of Corrosion Resistant Galvanizing Alloys (Birmingham), The University of Birmingham, 2005, $255 \mathrm{pp}$

7. J.J. Sebisty and R.H. Palmer, Hot-Dip Galvanizing with Less Common Bath Additions, Report, Department of Mines and Technical Surveys-Mines Branch, 1964, 40 pp

8. N. Gross, T. Nasch, and W. Jeitschko, Ternary Intermetallics with High Zinc Content: TT' ${ }_{2} \mathrm{Zn}_{20}(\mathrm{~T}=\mathrm{Zr}$, Hf, $\mathrm{Nb}$; T' $=\mathrm{Mn}$, $\mathrm{Fe}, \mathrm{Ru}, \mathrm{Co}, \mathrm{Rh}, \mathrm{Ni}$ ) with $\mathrm{CeCr}_{2} \mathrm{Al}_{20}$-Type Structure, J. Solid State Chem., 2001, 161(2), p 288-293

9. X. Su, N.-Y. Tang, and J.M. Toguri, Thermodynamic Evaluation of the Fe-Zn System, J. Alloys Compd., 2001, 325(1-2), p 129-136

10. J. Nakano, D.V. Malakhov, and G.R. Purdy, A Crystallographically Consistent Optimization of the $\mathrm{Zn}-\mathrm{Fe}$ System, Calphad, 2005, 29(4), p 276-288

11. G. Reumont, P. Perrot, J. Fiorani, and J. Hertz, Thermodynamic Assessment of the Fe-Zn System, J. Phase Equilib. Diffus., 2000, 21(4), p 371-378

12. W. Xiong, Y. Kong, Y. Du, Z.-K. Liu, M. Selleby, and W.-H. Sun, Thermodynamic Investigation of the Galvanizing Systems, I: Refinement of the Thermodynamic Description for the Fe-Zn System, Calphad, 2009, 33(2), p 433-440
13. R. Arroyave and Z.K. Liu, Thermodynamic Modelling of the Zn-Zr System, Calphad, 2006, 30(1), p 1-13

14. P. Chiotti and G. Kilp, Vapor pressure and thermodynamic properties of $\mathrm{Zn}-\mathrm{Zr}$ and $\mathrm{Zn}-\mathrm{U}$ alloys, Trans. Metall. Soc. AIME, 1960, 218, p 41-44

15. R. Arroyave, A. van de Walle, and Z.K. Liu, First-Principles Calculations of the Zn-Zr System, Acta Mater, 2006, 54(2), p $473-482$

16. P. Chiotti and G.R. Kilp, Zinc-Zirconium System, Trans. Metall. Soc. AIME, 1959, 215, p 892-898

17. B. Samson, The Crystal Structure of the Intermetallic Compound $\mathrm{ZrZn}_{22}$, Acta Crystallogr., 1961, 14, p 1229-1236

18. X.-A. Chen and W. Jeitschko, Preparation, Properties, and Crystal Structure of $\mathrm{Zr}_{5} \mathrm{Zn}_{39}$, a Vacancy Variant of the $\mathrm{Ce}_{5} \mathrm{Mg}_{41}$-Type, and Structure Refinement of $\mathrm{ZrZn}_{22}$, J. Solid State Chem., 1996, 121(1), p 95-104

19. Y. Liu, X. Su, F. Yin, Z. Li, and Y. Liu, Experimental Determination and Atomistic Simulation on the Structure of FeZn $_{13}$, J. Phase Equilib. Diffus., 2008, 29(6), p 488-492

20. D. Cook and R. Grant, Identification of the Iron-Zinc Phases in Galvanneal Steel Coatings by Mossbauer Spectroscopy and Xray Diffraction. Phase I: Characterization of the $\mathrm{Fe}-\mathrm{Zn}$ Intermetallic Phases, ILZRO Report: ODUDCC0193, 1993, p 1-108

21. C.H.E. Belin and R.C.H. Belin, Synthesis and Crystal Structure Determinations in the $\Gamma$ and $\delta$ Phase Domains of the Iron-Zinc System: Electronic and Bonding Analysis of Fe13Zn39 and FeZn10, a Subtle Deviation from the HumeRothery Standard?, J. Solid State Chem., 2000, 151(1), p 8595

22. X. Su, N.-Y. Tang, and J.M. Toguri, $450{ }^{\circ} \mathrm{C}$ Isothermal Section of the Fe-Zn-Si Ternary Phase Diagram, Can. Metall. Q., 2001, 40(3), p 377-384

23. G.P. Vassilev, K.I. Lilova, and J.C. Gachon, Phase Diagram Investigations of the Ni-Sn-Bi System, J. Alloys Compd., 2009, 469(1-2), p 264-269

24. X. Tang, F. Yin, X. Wang, J. Wang, X. Su, and N.-Y. Tang, The $450{ }^{\circ} \mathrm{C}$ Isothermal Section of the Zn-Fe-Ti System, J. Phase Equilib. Diffus., 2007, 28(4), p 355-361

25. N.-Y. Tang, X. Su, and J.M. Toguri, Experimental Study and Thermodynamic Assessment of the Zn-Fe-Ni System, Calphad, 2001, 25(2), p 267-277

26. H. Tu, X. Su, F. Yin, X. Wang, and J. Wang, $450{ }^{\circ} \mathrm{C}$ Isothermal Section of the $\mathrm{Zn}-\mathrm{Fe}-\mathrm{Nb}$ Ternary System at the Zn-Rich Corner, J. Alloys Compd., 2009, 485(1-2), p 270-274

27. P. Werner, L. Eriksson, and M. Westdahl, TREOR, a SemiExhaustive Trial-and-Error Powder Indexing Program for all Symmetries, J. Appl. Crystallogr., 1985, 18(5), p 367-370 